\title{
Klus - et middelalderligt valfartssted ved Flensborg
}

\section{Af Ole Harck ${ }^{1}$}

Ved den nordlige indkørsel til Flensborg ligger den lille forstad Ḱlus, som i slutningen af sidste århundrede blev bygget til skibsværftets arbejdere. Navnet Klus stammer fra en nu forsvundet landsby," der før i tiden lả længere mod vest på højderyggen ved den del af hærvejen, som i folkemunde kaldes Krumvejen. ${ }^{3}$ Her ligger $i$ dag den store gård Klusgård, hvis navn sammen med skovens navn, Klusris, er det eneste, der minder om det gamle Kilus. Klusris var i tidligere tid en del af en stor sammenhængende skov, der strakte sig fra Bramstedlund i Ladelund sogn til Jarlund i Valsbøl sogn og Kragelund i Bov sogn. ${ }^{4}$ En del af skoven i Bov sogn kaldtes Krakholdt; ${ }^{5}$ den yderste ende af skoven fra omkring Oldemorstoft blev efter Jonas Hoyer (1628) betegnet som Krokris." I løbet af årene blev Krokris dog opkaldt efter landsbyen Klus, hvorimod âen, der snoede sig igennem skoven, Krogå, efterhånden fik navnet Kruxå, i dag: Kruså. Navnet Krokris nævnes første gang i slutningen af det 14 . århundrede, hvor det bruges til nærmere stedfæstelse af en eneboerhytte ved vejen fra Flensborg til Bov.

Og hermed er vi ved sagen: det tidligere meget søgte valfartskapel ved Flenshorg, som skal være emne for denne lille betragtning.

Carsten Petersen har i bogen, der rummer hans undersøgelser over den slesvigske præstestands historie, gjort en del ud af et paveligt dokument, der er dateret til slutningen af det 14. århundrede. Her skrives følgende efter Carsten Petersen ${ }^{8}$ : "En af de sidste dage $\mathrm{i}$ det 14. årh. udsendte paven fra Roma en skrivelse til alle troende. I indledningen tales om dem, der gerne vil tjene Gud for bestandigt, at de má have et ensomt sted, fjernt fra alle verdens fristelser, for at hjertet ganske kan hengive sig til det guddommelige. Skove og huler må overlades dem, for at ikke 
verdens forfangelighed skal lede dem pá afveje. Så vil de stråle ved hellige gerninger sảdan, at Kristi troende allesammen tilskyndes til at give almisser og hjwlpe til med at bygge kirker, og aflad vil komme rigeligt fra det apostolske sæde. Så har nu Ludolf Swerk, en præst fra Lybæk stift, og en lægmand Wilhelm Uterlyre, i den hensigt at føre et eneboerliv taget sig for at opføre et kapel til are for den hellige Jomfru Maria og Augustin og Brigitte i en skov, som kaldes Chroxis-Krogsris i Slesvig stift. Der loves aflad til alle dem, som give af deres midler dertil, skænke bøger eller kalke etc. og derefter andagtigt besoge dette kapel, nâr det er bygget, på Marias eller Augustins eller Brigittes højlider i sand bod og bekendelse.

Hermed er en hel række enkeltheder belyste. Forst og fremmest - hvad der er af vigtighed for den arkxologiske undersøgelse -- havde man, da dette brev hlev skrevet under pave Bonifacius d. 9.s paveperiode, endnu ikke opfort noget kapel, men opførelsen var umiddelbart forestâende. Vi kan således datere kirkebygningen til omkring år 1400. For det andet er det interessant at fastslå, at stedet blev taget $\mathrm{i}$ besiddelse af eneboere, som her ved den vigtige forbindelsesvej mellem nord og syd ville udføre et arbejde for de vejfarende, for sâledes må vi vel tolke den kendsgerning, at de to eneboere ikke, sảdan som paven anbefaler det, søger ud i skove og utilgæengelige steder, men derimod lagger deres hytte ved den dengang meget trafikerede vej. Kapellet blev bygget til are for tre hellige; som det vil vise sig, er der en smule kludder i opfattelsen af, til hvem det nu i virkeligheden blev opført. Det kan være, at man oprindeligt havde tænkt på disse tre, men dette blev senere ændret. Af allerstørste vigtighed er desuden den kendsgerning, at det var tyske eneboere, der havde søgt mod nord. De var såkaldte »Klausnere og deres hytte en "Klause " disse udtryk blev hængende, også da eneboerlivet blev aflost af en mere eller mindre officiel kirkelig instans. Der tales senere officielt kun om kapellet, og hertil føjes så et eller flere navne på hellige mænd eller kvinder, mens man derimod $\mathrm{i}$ folkemunde taler om »Klausen " eller $\mathrm{i}$ datidens skrivemåde "de Klusz "."

Men kapellet blev bygget, og det har i lobet af kort tid vakt temmelig stor opmærksomhed, for allerede i $1427^{10}$ får minori- 
terklosteret i Flensborg af pave Martin d. 5. tilladelse til at opføre et kloster ved kapellet. Da denne pave dør kort tid efter, bliver der ikke noget ud af sagen, før hans efterfølger i sædet, pave Eugenius d. 4., bekræfter forgængerens tilladelse i 1431. I et brev til biskoppen $i$ Viborg overdrager han denne at meddele minoritermunkene i Flensborg tilladelsen. Denne er givet, efter at kongen, Henrik, som han kaldes $\mathrm{i}$ dokumentet, har givet sit samtykke til planen. Dog må det være en fejl, at kongen skulle hedde Henrik; der kan kun være tale om Erik af Pommern. Klosteret ved Klus skulle bebos af minoriter, og disse skulle have de til et kloster hørende rettigheder.

Klosteropførelsen var godkendt af kongen, men alligevel er sagen yderst uklar. Var den danske krone ejer af jorden omkring Klus, så havde den også ret til at bestemme de kirkelige forhold. Første gang en kongelig godkendelse kan have foreligget er i dokumentet fra 1427. Samme år dør også den holstenske hertug Henrik, og han skænkede ved sin død kapellet til Ryd kloster ved det nuværende Lyksborg. Denne donation bekræftes af hans brødre i $1433,{ }^{11}$ og samme år bevidnes overdragelsen af denne og flere ejendomme af klosterets abbed. ${ }^{12}$ Er der tale om en fejl fra Vatikanets side, for i det pavelige dokument kaldes kongen Henrik, efter navnet tilføjes så alle kongens titler, hvorefter der ikke længere kan være tvivl om, at der er tale om kongen? Det kan jo også forholde sig således, at hertugerne post mortem i broderens navn overdrager klosteret en ejendom, som de har røvet fra kongen ved deres erobring af Flensborg. Kilderne synes ikke at give oplysninger over det virkelige forhold. Indtil reformationen høres der ikke mere om de kirkelige forhold i Klus.

Det, der er opfort ved Klus, kaldes i brevet fra Rom for et oratorium ved Krocziis, af hertugerne betegnes det som kapellet eller oratoriet til Jomfru Marias ære på et sted, som vulgært kaldes for Krokris, og som ligger i Hanved sogn. Overdragelseskapitlet er skrevet på latin, men et forord er skrevet på tysk. Heri betegnes kapellet som liggende udenfor Flensborg.

Foruden de to eneboere kendes kun én præst ved navn. Ifølge en gammel flensborgsk krønikeskriver, Jonas Hoyer, ${ }^{13}$ er kapellet opkaldt efter Sct. Anna, jomfru Marias moder. Er dette tilfældet, så hed en af præsterne i Klus i 1480 Jens Jaspersen. ${ }^{14}$ Han var 
$P a ̊$ den $\phi v e r s t e$ fiskedams vold står ldag endnu denne grænsesten med årstallet 1601 .

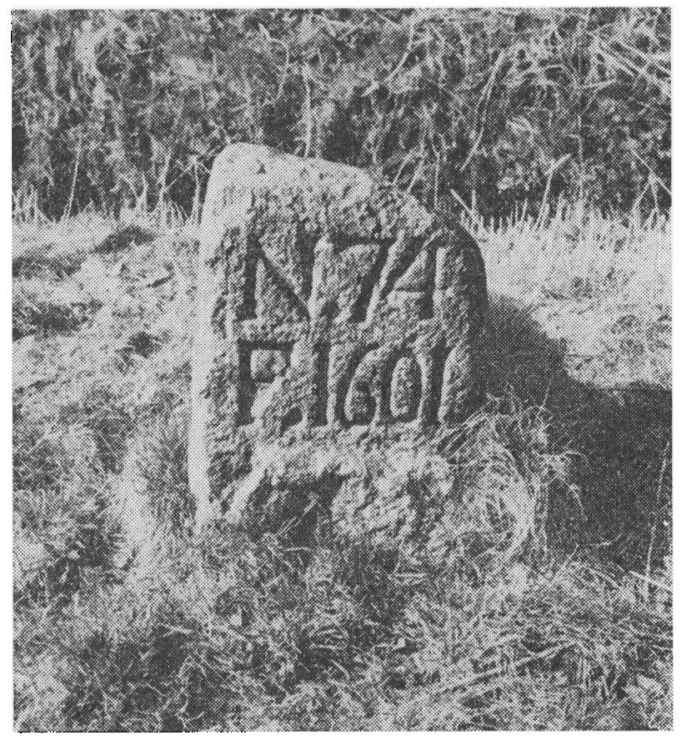

medlem af Hellig Legemsgilde i Flensborg og findes i fortegnelserne over medlemmerne for dette år.

I gamle fortællinger om Klus berettes altid om, at der er fundet krykker og rester af bidsler. ${ }^{15}$ De skulle stamme fra helbredte mennesker og dyr. Man kunne her ved bøn og andagt helbrede syge, derefter blev de helbredtes ting efterladt, ligesom det også fortælles, at man kun behøvede at medbringe noget, der tilhørte det menneske eller det dyr, der skulle helbredes. Efter at genstanden var lagt ned foran helgenbilledet, kunne den syge blive rask igen.

Selv om det ikke blev til noget kloster i Klus, har der dog været flere præster. De beboede et hus, som $1539^{10}$ blev taget $i$ brug af den første protestantiske præst i Hanved sogn, Hartvig Davidsen også kaldet Bidsen. Om denne præst ${ }^{17}$ fortælles det, at han først ikke ville antage Luthers lære, men drog til Hamborg, hvor han kom på "bedre tanker" og så vendte hjem igen til menigheden. Han døde 1566. Kapellet blev nedbrudt efter reformationen, ${ }^{18}$ og stenene anvendt til reparation af Hanved kirke.

Da kapellet fra 1433 tilhørte Ryd kloster i Lyksborg, tilfaldt 
det ligesom den ovrige del af dette klosters gods kongen i $15444^{\text {*0 }}$ Ryd kloster og omliggende land blev skænket hertug Johan den Yngre i 1582, hvorefter slottet blev opfort, men ejendommeligt nok beholdt kongen meget længe de tidligere klosterbesiddelser omkring Klus som ejendom.

Til kapellet horte de sandsynligvis af kapellets beboere anlagte fiskedamme Musbæk- og Moorbæk-dam." ${ }^{-n}$ Af disse damme findes stadigvak lave jordvolde i terrænnet. Hvorvidt navnene til disse to fiskedaume er opstâet, efter at dammene var anlagt eller er overtaget fra folkemunde, er usikkert. Det er dog påfaldende, at navnet Moorbæk-dam med stavelsen » Moor" synes at være af tysk oprindelse ligesom navnet Klus. Om vi i betegnelsen Moorbæk har det navn, som man i gamle beretninger finder som stedangivelse for en gammel borg ved Flensborg, ${ }^{21}$ kan ikke afgøres med sikkerhed. Der fortalles et sted om en borg ved "Flensbeck ved Mordbeck i Ramsherred mark «. Ramsherred var den nordlige del af byen. Der findes ikke nord for byen andre bække end det i dag som Laksebæk betegnede vandløb, der i ældre tid kaldes Moorbæk; herved ligger disse to fiskedamme. Et kongeligt dokument $^{22}$ fra året 1777 med kongelig underskrift bekræfter en aftale mellem kongen og en flensborgsk købmand, Jacob Kahl, om salget af fiskedammene. Disse blev så senere solgt videre til familien Rønnekamp, Klusgård. Sa lange blev noget af det tidligere klostergods pâ kronens hænder.

Efter at kapellet var nedbrudt, byggedes der pa jorden omkring kapellet fire små husmandssteder, ${ }^{2 a}$ der ifølge et dokument fra âret 1614 fik tildelt forskellige rettigheder. Disse brug blev sammen med den dertil hørende jord solgt til familien Rønnekamp, der byggede gården Klusgârd.

Ved opførelsen af den store gárd stıdte man pá de sidste rester af kapellet. I âret 1805 har man ved bygningen af de store lader fundet en del bygningsgrus, og ved udgravningen af en kartoffelkælder i 1833 fandt man et skelet. ${ }^{24}$

Hvornår møder man for forste gang navnet Klus? I de gamle dokumenter om overdragelsen af kapellet til klosteret i Rus Regis, og i tilladelsen til at bygge et kloster ved Klus tales der hele tiden om kapellet ved Krokris eller om Hanved sogn. Hvordan navnet 


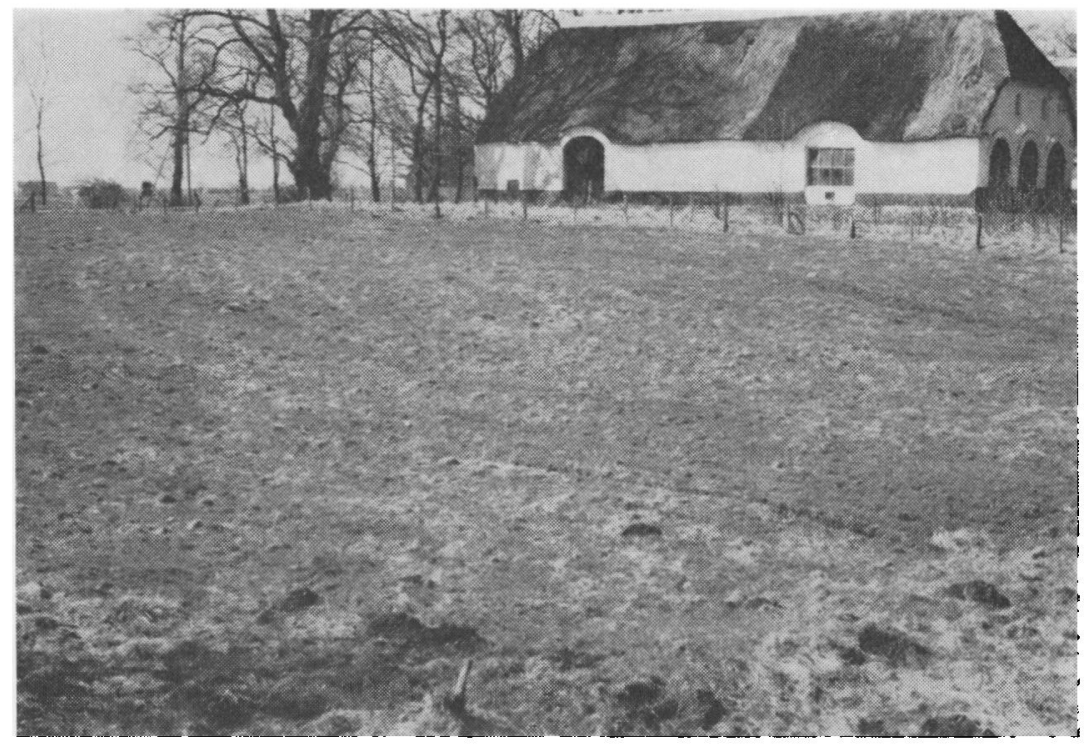

Klusgärds sydlige lude set fru syd. Mellem det store tra og laden har kapellet ligget. kwkken af hegnspwle foran laden forer lige over det fundament, der muliguis har varet en prastegård.

er fremkommet og blevet til en stedbetegnelse synes at fremga af et brev skrevet af den tidligere borgmester i Flensborg, Haye Payssen. ${ }^{-5}$ Det er en forpligtelse til Christian 1. i anledning af Payssens benadning for deltagelse $\mathrm{i}$ oproret mod kongen. Brevet er dateret i 1473, og der skrives bl. a.: ». . . hefft syne gnade my ok gegunnet in syner gnaden lande unde gebeden to wesende, uth genommen to Flensborgh, unde dar nicht negher to kommende alse Adelbu kerken und de Kilusz, dar unse leue vrowe gnedich is, by Flensborgh vorben belegen ". Her sidestilles Adelby kirke som stedbetegnelse med kapellet i Klus. Men det hedder endnu "de Klusz", endnu er det kapellet, ikke stedet, der har navnet.

I et uddrag af Gotschlak von Alefelds regnskab ${ }^{30}$ over indtægter og udgifter pâ hertug Frederiks vegne for ärene 1502-05, står følgende vending: Flensborch in reditu: »Interste dem schroder knechte Bernhde, wente he vorlecht hadde vor etc sindel. ijsz Item offerde myn g. $h$. tor Klus vor Flensborch ijsz. « Her er Klus 
allerede blevet en stedbetegnelse, der er nemlig ingen hentydning til kapellet.

I Dankwerths kort over Flensborg, der stammer fra 1648, findes Klus brugt som navnet pa en landsby. Og i senere dokumenter kommer det samme til udtryk. Med denne udvikling af navnet Klus, hvor det er bygningen, Klausen, der fører til stednavnet, skulle den af Carsten Petersen ${ }^{27}$ repræsenterede mening om, at Klus og dermed Klusris ikke er en plattysk forvanskning af Klause, men snarere en naturlig lydændring af Krogsris ved Krogå, ikke længere kunne holdes.

En arkæologisk undersogelse af kapellet har indtil i dag kun indskrænket sig til at fastslå bygningens nøjagtige beliggenhed. Som udgangspunkter for undersøgelsen havde jeg de gamle beretninger $i$ topografierne om fund af bygningsgrus $i$ jorden ved Klusgård. Desuden var skeletfundet i kartoffelkælderen et godt fingerpeg $i$ retning af at finde frem til kapellets beliggenhed. De første undersøgelser var dog skuffende, idet der nok kom bygningsgrus, men det syntes at stamme fra ladens bygning. Dog kunne der ved hjalp af en sonde fastslås en ca. $15 \mathrm{~m}$ lang stensæetning parallel med den sydlige lade ca. $30 \mathrm{~m}$ syd for denne. En lille søgegroft igeunem denne stensætning viste en regelmæssig lagt stenbrolægning. Det hele gjorde indtryk af at have haft en eller anden tilknytning til en bygning. Dog var det ikke kapellet, der var fundet, for der fandtes intet bygningsgrus.

I sensommeren 1961 fik jeg meddelelse om, at der var fundet en ny stensætning. Fundet var gjort af kabelarbejdere lige vest for Klusgârds sydlade, i hvis vestlige ende kartoffelkælderen, hvor skelettet blev fundet, endnu findes den dag i dag. En søgegrøft i dette område gav klarhed over, at der i dette tilfælde var: tale om de sidste rester af det omkring 1400 byggede kapel. To rækker med favnstore sten havde imellem sig en bunke ikke særligt ordnede sten $\mathrm{i}$ alle størrelser. Udenfor den vestligste stenrække var derimod en ordnet stensætning af sten, der i størrelse' var lidt større end en knyttet mandsnæve. Mellem denne stensætning og laden fandtes på et sted et temmeligt tykt lag af bygningsgrus, hvori der lå halve munkesten, tagsten og rester af søjler af brændt ler. Dette lag holdt dog hurtigt op igen, da man havde gravet det op, sandsynligvis for at få grus til veje eller 


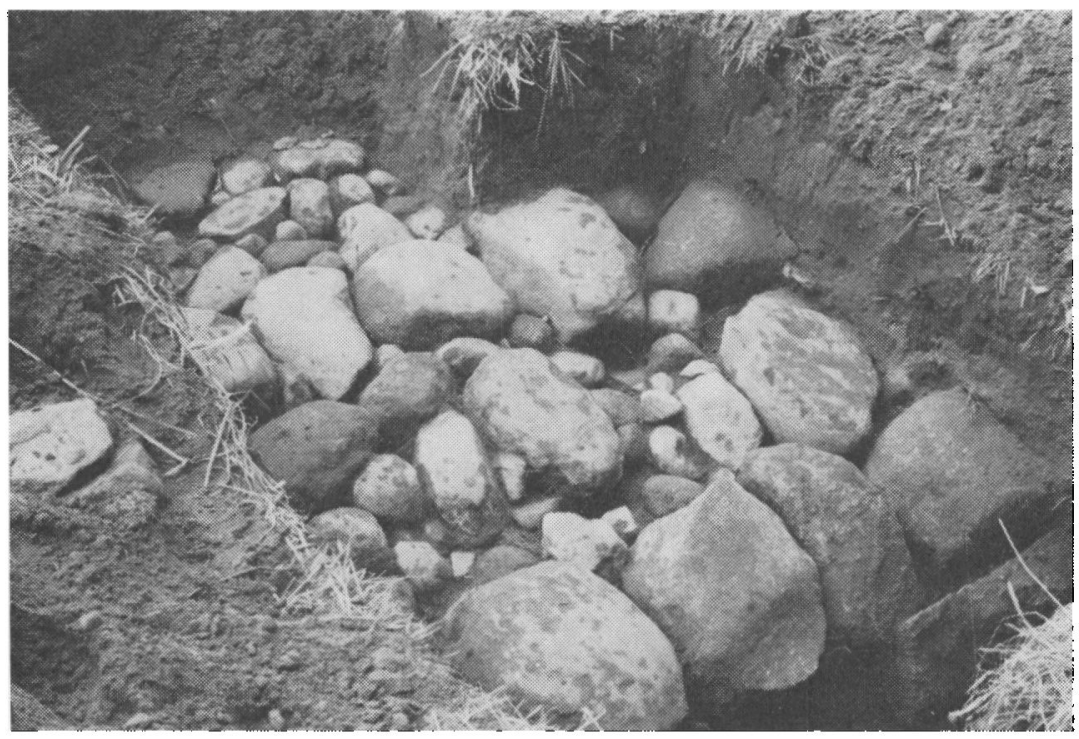

Kapelle/s fundament set fra ost.

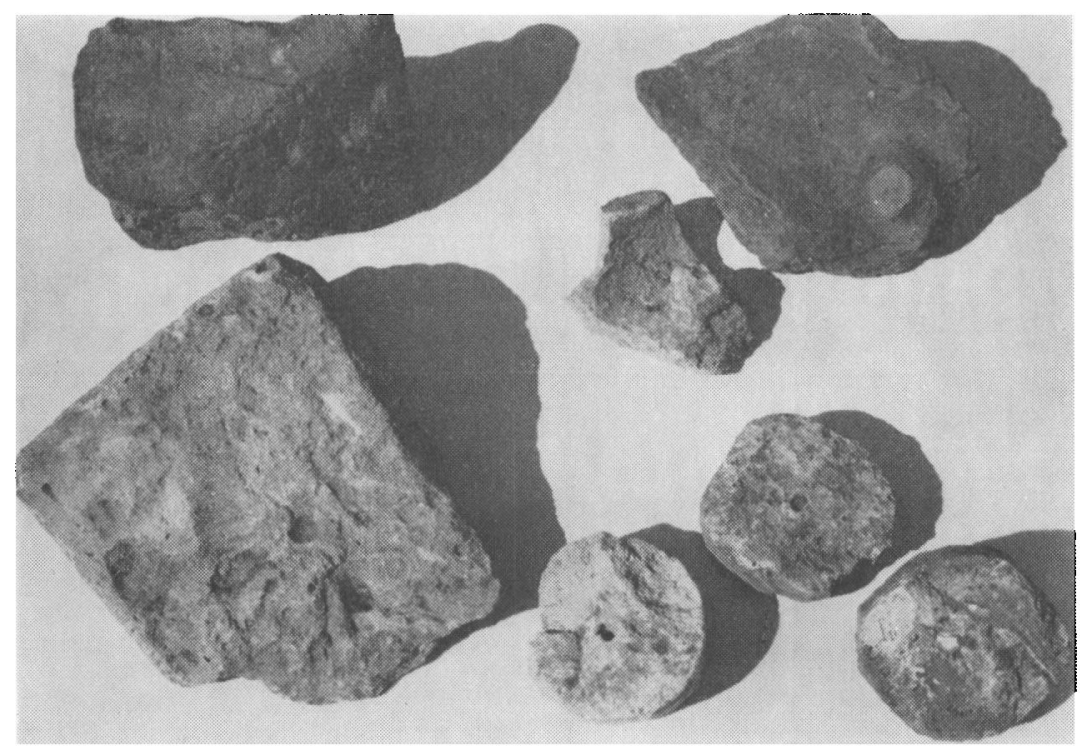

Enkelte af de fundne munkesten, tagsten med fremspringende hage og søjlerester. Stenenes farver er røde og gule, de samme som forekommer i Hanved kirke. 
støbning på et tidspunkt, da gården Klusgárd endnu var i fuld drift.

Søgegroftens profil gav folgende billede: Stenswiningen havde kun et lag sten. Disse var lagt således, at den flade side vendte nedad. I umiddelbar forlængelse heraf fulgte det omtalte lag bygningsgrus. Dette var blevet gravet bort $i$ den ovrige del af søgegrøften. Nu viste det sig, efter at humuslaget var bortgravel, at den naturlige undergrund ikke kom til syne, men at et lag fint sand dækkede groftens bund. Ved at grave ned til ca. 1,5 m dybde, kom et ca. tyve cm tykt lerlag til syne, hvori der bl. a. lå enkelte dyreknogler. Og under dette stampede lerlag lå så den faste undergrund. I sandlaget havde vi ikke fundet noget bygningsgrus, men lige ovenpå lerlaget lå halve munkesten og andre murbrokker.

Hvordan skal detle nu forklares? Måske kan det følgende give en smule mere hold på sagen: Da kapellet blev opfort, lagde man efter at have gravet et lille stykke ned $i$ jorden to rakker store sten og imellem disse sten af forskellig størrelse. Udenfor det, der senere skulle bære bygningen, havde man, som man gor på landet den dag i dag, lagt en stensætning af mindre sten, blandt andet for at forhindre regnvandet $i$ at grave en rende omkring bygningen. Efter at et stykke af muren var opført, opdagede man, at undergrunden var alt for fugtig til at f.eks. træværk kunne ligge lige på jorden. Et stykke fra fundamentet havde man, for at jorden ikke skulle skride og bygningen derefter synke sammen, gravet ned $\mathrm{i}$ undergrunden og så derpå lagt et lag stampet ler. Hermed skulle fugtigheden holdes borte. Mens dette lag fik tid til at tørre, byggede man videre på kapellet og smed af og til en halv ubrugelig mursten ned pâ lerlaget. På taget var man endnu ikke begyndt, da der ikke er fundet tagstensrester på lerlaget. Så blev arbejdet standset for et par dage, for at der kunne fyldes fint, tort sand i udgravningen. I dette sandlag blev der så godt som intet bygningsgrus fundet. Derefter havde man fået et tort lag til kirkerummet. Endnu ved udgravningen kunne man mærke forskel mellem sandlagets tørhed og den fugtige lerjord, som undergrunden bestâr af. Lidt højere end stensætningen har den gamle overflade været, mens kapellet var i brug, for bygningsgruset er sikkert faldet ind i bygningen, da den blev ned, 


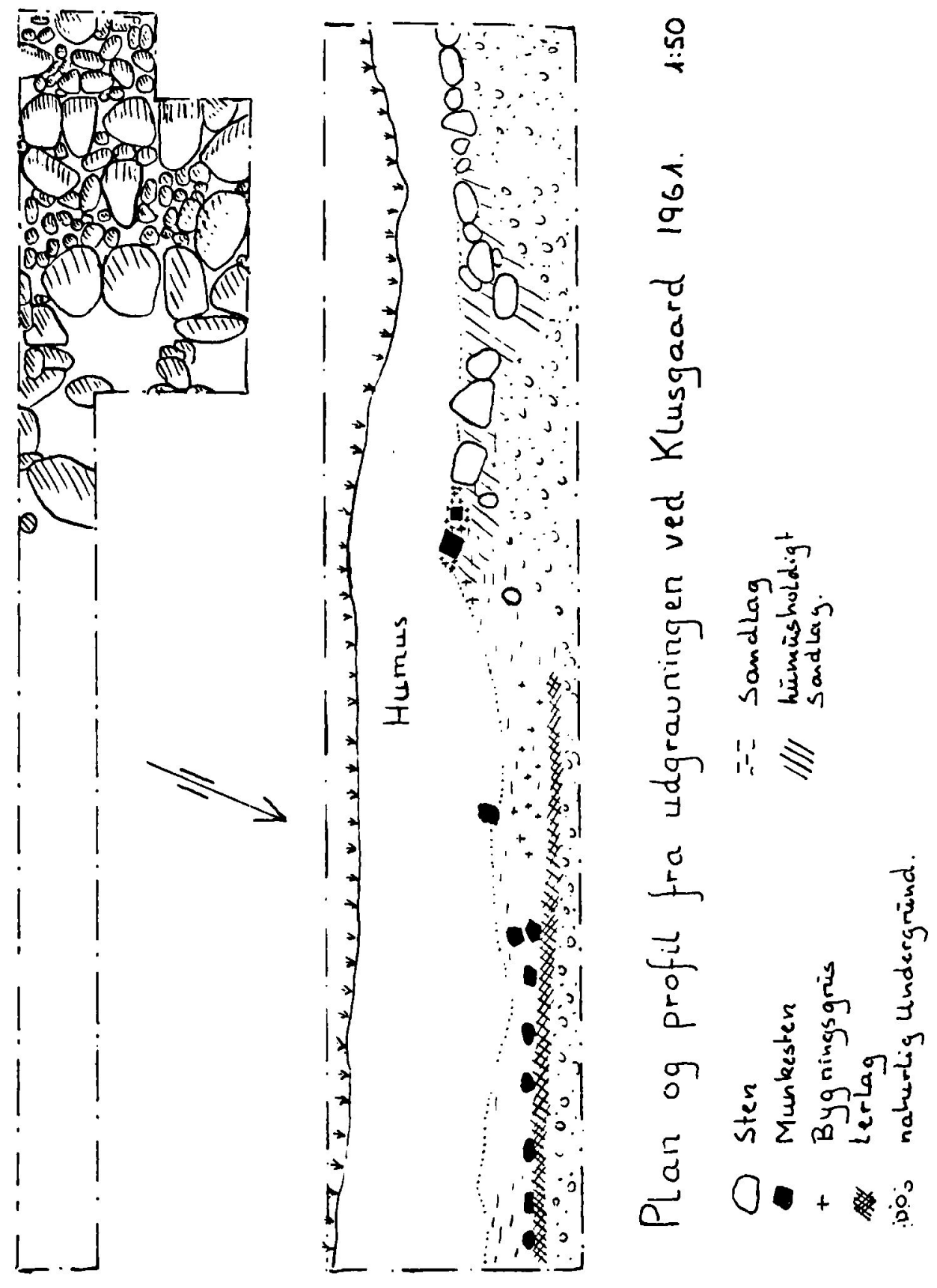


revet. At der i dag er henved $50 \mathrm{~cm}$ jord ovenover dette lag, skyldes sandsynligvis planeringen efter bygningen af laderne.

Noget af det, der overraskede mest, var fundamentets svaghed. I gamle kirker finder man til dels fundamenter, der gâr meget dybt ned i jorden. Men dog har andre bygninger, der har været langt større end kapellet ved Klus, haft fundamenter af tilsvarende art, selvom disse bygninger dateres langt senere.

Det skelet, som blev fundet i 1833 , har i alle tilfælde været placeret meget tat ved kapellets kor. Om det sa har ligget udenfor eller inde i selve bygningen, er ikke til at afgøre.

Er resterne af den bygning, hvis fundament blev fundet ca. 30 meter syd for laden, så den præstegård, hvori Hanvedpræsten boede i 1539? Bygningens størrelse og placering $i$ forhold til kapellet kunne tale for denne tolkning.

Ud over disse to søgegrøfter, som førte til at placere anlægget nærmere, er der ikke foretaget noget videre arkæologisk set. En fuldstændig udgravning af kapellet vil sandsynligvis kun føre til, at man kan få klarhed over størrelsen og udstrakningen af anlægget.

Hugo Matthiessen ${ }^{28}$ kommer i sin fortræffelige bog om Hærvejen også ind pá den »krumme" vej, den vej, der forte fra Bov forbi Klus til Flensborg, og herfra sydpâ. V'ejene stødte sammen igen ved Jaruplund. Matthiessen går meget kraftigt imod den tit fremsatte mening om, at Krumvejen skulle være den oprindelige Hærvej. Er dette nu rigtigt? Mâske gælder det i senere tid, da studehandlen dominerer. En kartografisk sammenstilling af kirker, kapeller og hellige kilder langs Hærvejen viser, at Flensborg på dette område smukt føjer sig ind $i$ kæden af alle de steder, de vejfarende $i$ katolsk tid kunne opsøge. På strækningen mellem Bov og Flensborg ligger ved Nyhus en hellig kilde. ${ }^{20}$ Det første, den vejfarende mødte i Flensborg, var et Sct. Gertruds-kapel lige indenfor den nordlige byport. Og det dertil horende Sct. Gertrudsgilde havde jo, hvad Hugo Matthiessen udtrykkeligt nævner, den opgave at stå fattige pilgrimme bi pä deres rejse. På vejen udenom Flensborg ligger der ingen hellig kilde, intet kapel eller kirke. Det næste sted er først Oversø kirke. De ting, Hugo Matthiessen anfører som beviser for, at vejen gik udenom Flensborg, er dokumenter, der alle er senmiddelalderlige. På dette tidspunkt kan det 
meget vel være muligt, at man fra flensborgsk side har onsket at fí alt kvaget udenom byen.

Ved al lagge borgen Nyhus ved Krumvejen, ikke ved den anden, spærrede man ikke alene tilgangen til Flensborg, men tillige hele trafikforbindelsen til lands mellem nord og syd. Helt nye opdagelser indenfor Flensborgs bymure, synes at pege $i$ samme retning. Her er det lykkedes for den kendte hjemstavnsforsker J. Røschmann ${ }^{30}$ at fastslå et borganlæg ved den nuværende Fruekirke, et anlæg, der måske kan føres tilbage til ca. år 1200. Andre endnu ikke fremdragne borganlæg ved Flensborg, ikke ved Hugo Matthiessens Hærvej, synes at tale for, at man i det mindste for årene indtil 1500 har brugt vejen over Flensborg.

At den verdslige magt $i$ tidlig middelalder har erkendt vejstykkets betydning, for Hærvejen fra Flensborgs beskyttende mure fører sydpå i et åbent usikkert land, ses deraf, at der fra Flensborg til Bov findes rester af flere borganlæg enten i terrænet eller nævnt $\mathrm{i}$ de historiske kilder. Fra kirkelig side har man villet give datidens pilgrim en passende afsked, før han vandrede videre sydover, hvor han skulle gå længe, inden han fandt en kirke eller et kapel. Herved kunne Klus opnå en sådan betydning, at endog flere paver har givet tilladelsen til en klosteropførelse, og at holstenske hertuger efter erobringen af Flensborg i 1431, sandsynligvis for at betydningen af Ryd kloster ikke skulle svækkes ved et stærkt kloster ved Klus, skænkede kapellet til Ryd kloster og herved forhindrede den danske konge $i$ at få et stottepunkt i gejstlig og verdslig henseende, hvad der kun kunne skade deres interesser. 


\section{HENVISNINGER}

1. Stor tak for hjælp ved de arkæologiske undersugelser skylder jeg ejeren af Klusgård, Chr. Ronnekamp. Jeg vil også takke stud. rer. nat. Torkild Tonnsen, Flensborg, for hjalpsomhed ved udgravningen.

2. Landsbyen er næunt flere gange, f. eks. findes den på Dankwerths kort over hertugdømmerne fra 1648 .

3. Hugo Matthiessen, Hærvejen, 1951, s. 127.

4. M. Mørk Hansen og C. L. Nielsen, Kirkelig statistik over Slesvig stift, Kbhvn. 1864, bd. 2, s. 161, anm. 3.

5. Carsten Petersen, Slesvigske Praster, 1938, s. 20 ff.

6. Mork Hansen, s. 161, anm. 3.

7. Carsten Petersen, s. $20 \mathrm{ff}$.

8. Carsten Petersen, s. 20 ff.

9. H. C. P. Sejdelin, Diplomatarium Flensborgense. Bd. I, s. 736.

10. Sejdelin s. $385 \mathrm{ff}$.

11. Sejdelin s. $413 \mathrm{ff}$.

12. Sejdelin s. $414 \mathrm{ff}$.

13. Mork Hansen, s. 161, anm. 3.

14. Carsten Petersen nævner, at den sidste eneboer i Klus hed Jens Jaspersen. I fortegnelse over medlemmer i Hellig Legemsgilde, en fortegnelse, som C. P. ogsî henviser til, findes kun en hr. Jasper, men muligvis er der tale om den samme. Sejdelin, s. 394.

15. F. eks. i H. Oldekop, Topographie des Herzogtums Schleswig, Kiel 1906, s. 82 ff. og i Trap, Hertugdømmet Slesvig, 1864, s. 465.

16. Carsten Petersen, s. 20 ff.

17. Mork Hansen, s. 177.

18. Oldekop, Mørk Hansen og Trap.

19. Jensen, Angeln, 1923, s. 184-86.

20. Oldekop, s. 82.

21. En fremstilling over borge og befæstningsanlag i Flensborg vil inden længe blive givet $i \mathrm{~J}$. Roschmanns bog om de arkæologiske forhold i Flensborg by og amt. Bogen er for tiden i trykken. En lille beretning i populær form har stâet i Flensburger Tageblatt 29. 12. 61. Det er fra denne artikel af J. Roschmann, at nævnte vending er taget.

22. Dette dokument overtog familien Ronnekamp, Klusgård, da den kobte fiskedammene ved Slukefter, som stedet hedder i dag. Dokumentet er stadig i familiens eje.

23. Oldekop, s. 82.

24. J. v. Schroder, Hertugdommet Slesvigs topografi, oversat af Chr. Wollesen. 1854, s. 267.

25. Sejdelin, bd. I, s. 736 .

26. Sejdelin, bd. II, s. 933.

27. Carsten Petersen, s. $20 \mathrm{ff}$.

28. Hugo Matthiessen, Hærvejen, 4. udg., 1951, s. 127.

29. Mundtlig beretning af hr. Chr. Ronnekamp, Klusgärd. Kilden kaldes Haraldskilden. Til kilden knytter sig et sagn.

30. Roschmann, se anm. 21. 